\title{
Bifaces in plain sight: testing elliptical Fourier analysis in identifying reduction effects on Late Middle Palaeolithic bifacial tools
}

\section{Kamil Serwatka}

\section{Abstract}

Nowadays, geometric morphometrics are being widely implemented in lithic studies. Their application is driven by the powerful methods of data analysis offered by morphometric computer software. Additionally, computer programs for digital shape analysis are freeware and easy to handle, even for a non-morphometrician. The results achieved with this software yield interesting conclusions and they offer a new perspective on lithic tools. This presents morphometrics as a potentially useful methodological tool in the field of lithic analysis, which often has to deal with artifacts morphology. The aim of this study is to test the utility of basic shape analyses included in the PAST (Palaeontological Statistics) computer program, and especially elliptical Fourier analysis, in identifying reduction effects on Late Middle Palaeolithic bifacial tools. For this purpose, an assemblage of 147 bifacial tools from Southern Poland was analyzed. The sample comprised of Keilmessergruppen handaxes, Keilmesser and Late Middle Palaeolithic leaf points. The results reveal patterned changes in artifacts proportions, which may have been caused by continuous resharpening/reduction as well as by gradual alteration of tools design, due to their changing function.

Kivonat

\begin{abstract}
A bifaciálisok síkján: a kőeszköz redukció hatásának mérése a késői középső paleolitikum bifaciális eszközein elliptikus Fourier analízis segítségével

A geometrikus morfometria ma széles körben alkalmazott módszer a kőeszköz kutatásban. Alkalmazásának fő mozgatórugója a számítógépes szoftverekben rejlő hatékony adatelemzés lehetősége. A hatékonyságon túl a digitális formaelemző szoftverek ingyenesek és könnyen alkalmazhatók, még azok számára is, akik nem morfometriai szakemberek. A szoftvert alkalmazva érdekes eredményekre tarthatunk számot, ami a kőeszközök értékelésének új perspektíváit nyújtja. A morfometria a kőanalízis morfológiát érintő kérdéseit illetően hasznos módszer lehet. E tanulmány célja a PAST (Palaeontological Statistics) szoftver „elliptikus Fourier analízis” alkalmazásának tesztelése a késői középső paleolitikum bifaciális eszközein. 147 lengyelországi bifaciális eszközt vontunk vizsgálat alá, hogy megállapítsuk forma és kőeszköz redukció kapcsolatát. A mintát Keilmessergruppe szakócák, Keilmesser-ek és késő középső paleolitikus levélhegyek alkották. A vizsgálat a formai arányok változásában sajátos mintázatokat talált, ami utalhat folyamatos újraélezésre/redukcióra, illetve az eszközök dizájnjának fokozatos módosítására, ami az eszközök funkciójának változásaival függhet össze.
\end{abstract}

Keywords

Kulcsszavak
Late Middle Palaeolithic, geometric morphometrics, Keilmesser, handaxes, leaf points

Késôi középsô paleolitikum, geometrikus morfometria, Keilmesser, szakócák, levélhegyek
Author / Szerző

Cite as / Hivatkozás

Article history /

Kézirat történet

Copyright / Jogok
Institute of Archaeology, Wroclaw University, 48 Szewska Street, PO BOX 50-139 Wroclaw, Poland Email: kamserw@gmail.com

Serwatka, K. (2015) Bifaces in plain sight: testing elliptical Fourier analysis in identifying reduction effects on Late Middle Palaeolithic bifacial tools. Litikum 3: 13-25. https://doi.org/10.23898/litikuma0009

Received // Érkezés: 2015. 02 . 04. Accepted // Elfogadás: 2015. 09. 25. Published // Közzététel: 2015. 11. 16.

(c) 2015 Serwatka. This is an open-access article distributed under the terms of the Creative Commons Attribution License, which permits unrestricted use, distribution, and reproduction in any medium, provided the original author and source are credited. // Ez egy nyílt hozzáférésú publikáció, amit a Creative Commons 4.0 licensze véd. A termék szabadon használható, terjeszthető és sokszorosítható az eredeti szerző és forrás megjelölése mellett.

\section{Introduction}

During the past few years, landmark-based morphometrics were repeatedly applied as a methodological tool in numerous lithic studies (i.e. Buchanan-Collard 2010; Lycett et al. 2010; Iovita 2009; Charlin-González-José 2012; ErenLycett 2012). Nowadays, geometric morphometry is used as an aid in artefact classification (Buchanan et al. 2007), for the evaluation of the morphological diversity of lithic assemblages (Azavedo et al. 2014) or as an indicator of the reduction effects on stone tools (Iovita 2011; Thulman 2012). This considerable dissemination of geometric morphometry in lithic studies is most likely caused by the promise of powerful statistical methods of shape analysis offered by 


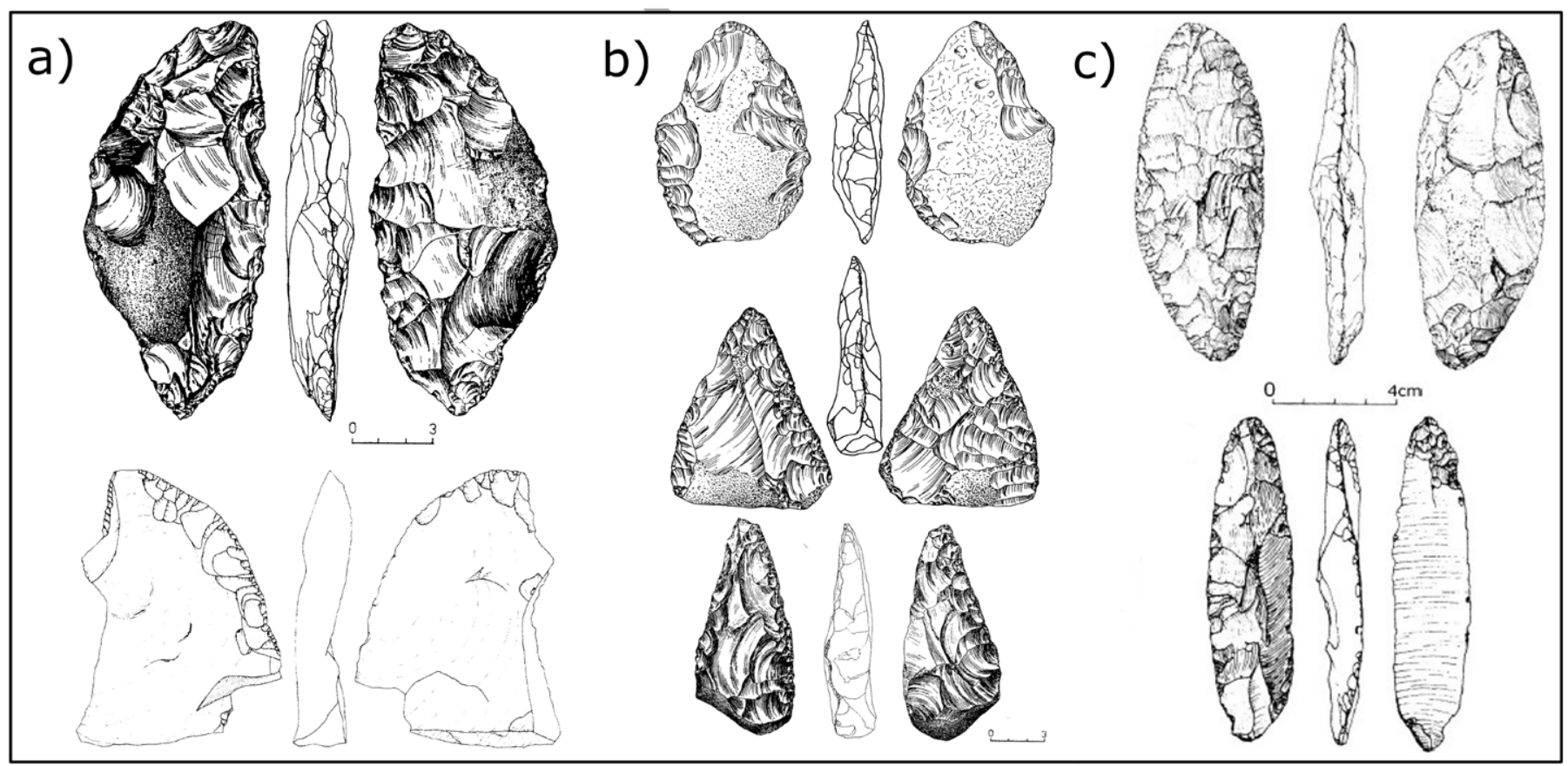

Figure 1. Types of bifacial artifacts considered in the study. a: Keilmesser; b: handaxes; c: LMP leaf points (after Kozłowski 2006; Cyrek 2002; Chmielewski 1961). //

1. ábra. A tanulmányban említett bifaciális eszközök. a: Keilmesser; b: szakócák; c: levélhegyek a késő középső paleolitikumból Kozłowski 2006; Cyrek 2002; Chmielewski 1961. nyomán.

various morphometric software and a relatively easy way of handling of those specialized computer programs.

Due to the emphasis, which geometric morphometry puts on the overall shape of analyzed objects, lithic studies involving morphometrics often focus on bifacial tools. Of all other stone tools, bifaces were made by shaping comparatively large raw material blanks into desired forms. This process may have incorporated the utilization of imposed patterns of artifacts design (or the so called "mental templates"), as well as individual concepts of tool making (Wenban-Smith 2004). There exists a widely accepted notion, that bifaces contain information transcending beyond simple requirements of lithic technology or utilitarian needs (Wynn 1996; Kohn-Mithen 1999; Porr 2005). Some researchers agree that even the oldest known bifacial tools were made with a sense of foresight and planning, and that the process of their production may have involved the use of complex cognitive abilities (i.e. Gowlett 2006; Feliks 2008). This encourages many scholars to use geometric morphometrics in bifacial tools analyses. Given the computing capabilities of morphometric software, it is possible to compare shapes of many objects simultaneously and to seek out patterns in their shape variability, which are hard to grasp using standard metric attributes. Given these advantages, morphometrics stand out as an accurate analytical tool, which can yield potentially interesting results.

Geometric morphometrics are commonly used within the case studies regarding finely crafted bifaces, such as Paleoindian points (see references above). There have been approaches dealing with Lower and Middle Palaeolithic handaxes as well as Keilmesser in this manner (for example the works by Costa 2010; Iovita 2009, 2010, 2011; IovitaMcPherron 2011), but such approaches still seem scarce.
Lower and Middle Palaeolithic bifacial tools are often highly variable due to their general asymmetry and they hardly fit into typological terms. Particular difficulties in the process of the identification and classification of Middle Palaeolithic bifacial artifacts can be observed by looking at the state of the research on Keilmessergruppen handaxes and backed knives (subsequently Keilmesser) (i.e. Hauser 1916; Bosinski 1967; Sobczyk 1975; Richter 2000, 2002; Ruebens 2006). Given the strong inclination towards the production of various bifacial tools in this cultural unit, it is often hard to distinguish artifact types, since one form merges into another. Despite these difficulties there exists a strong notion that Middle Palaeolithic stone tools, and especially Keilmesser, were frequently resharpened and reworked, which is considered one of the main reasons for their diversity (Dibble-Rolland 1990; Jöris 1994, 2001; Richter 1997; Pastoors-Schäfer 1999; Pastoors 2001; Migal-Urbanowski 2006). Bearing in mind the value of the studies listed above, it should be emphasized that most of them are based on scar pattern analysis. Despite the utility of this method in terms of understanding of stone tools use life, scar pattern analysis carries a heavy load of arbitrariness. The recognition of scar pattern alignments is mostly carried out using qualitative traits, which serve as an indicator of the alleged subsequent stages of reduction. In the author's opinion, relying solely on such criteria can lead to the misperception of reduction as an imposed scheme and as something that, eventually, must have happened to all tools with specific morphology.

The first aim of this paper is to test whether the typological categories such as handaxes, Keilmesser and leaf points coincide with the results of geometric morphometric analysis. It is important that we know if in the perspective of a statistical shape analysis LMP bifacial tools remain separate classes. This doubt stems on the fact that most geometric 
morphometrics recognize shape of objects only as a two dimensional outline (Zelditch et al. 2004). The other problem is that archaeologists often use subjective terms of shape description in their classifications. This may lead to intra-observer errors and cause discrepancies between the outcome of classification and the result of a strictly quantitative analysis. If this result will be positive, the second objective will be to evaluate whether there are any indications of reduction effects in the studied assemblage. This concerns mainly Keilmesser, but also handaxes. The author expects that the effects of reduction should appear only on the maintainable, or "active" parts of tools (see below) and they should occur as diminishing of these active parts.

\section{Keilmessergruppen handaxes}

The most descriptive model regarding handaxes reduction through resharpening was created by S.P. McPherron (1995, 1999, 2000, 2003). It was originally developed for Acheulean large cutting tools, but the model is sufficiently broad to be used for other forms of handaxes as well. By studying the African Acheulean handaxe assemblages, McPherron noticed, that most specimens show a pattern of reduction involving mainly the rejuvenation of the tip. This resulted in the transition from pointed to oval morphology in handaxes shape (McPherron 1995, 1999).

Considering Keilmessergruppen handaxes, the observations made by M. Urbanowski (2009) are worth mentioning. He had noticed, that some preforms with handaxe-like morphology from Wylotne Rockshelter were reworked into Keilmesser by breaking off one of the edges (the so called "Wylotne method").

\subsection{Keilmesser}

Keilmessergruppen backed knives were first recognized as a separate typological category by S. Krukowski (1939-1948). Later on they were formally defined by W. Chmielewski (1969). Initially, one of the most distinctive features of these artifacts was the paraburin scar resulting from a blow made at the distal end of the tool. This 'Pradnik technique' proved to be a convergent technical feature, which emerged independently in geographically distinct regions, probably as a method of resharpening the working edge (Schild-Wendorf 1977; Marks et al. 2002; Solecki-Solecki 2004).

Keilmesser are highly variable in terms of morphology (Fig. 1: a), which is partly conditioned by the form of accessible raw material blanks (Jöris 2006: fig. 6). Another widely accepted idea is that the reason for such great morphological diversity of these implements was the recurrent rejuvenation of the working edge. Several studies were dedicated to the problem of Keilmesser rejuvenation (i.e. Jöris 1994, 2001; Pastoors-Schäfer 1999; Pastoors 2001). Regarding the studied sample, the experimental approach by W. Migal and M. Urbanowski (2006) occurs as the most relevant. According to the results obtained by the mentioned authors, the consecutive repairs would significantly alter the proportions of Keilmesser. The most obvious outcomes would be: diminishing of Keilmesser elongation, alteration of the shape of the working edge (from convex to straight to concave), diminishing of the angle between the base and the working edge (extending the asymmetry of the tool).

\section{The reduction/resharpening concept}

The idea that Middle Palaeolithic tools were resharpened derives from the work of American researchers, particularly N. Rolland (1988) and H. Dibble (1984; 1987; 1995). Resharpening seems to be a natural outcome of the utilization of at least some of the stone tool forms. Among the most important factors affecting the occurrence of resharpening in bifacial tools, most researchers point out the availability of good quality raw materials, the distance to their nearest outcrops and the intensity of hunter-gatherer mobility (i.e. Shott 1995; Shott-Weedman 2007; Kelly 1988). According to Middle Palaeolithic contexts, most of these information are often not available due to the fragmentariness of archaeological data. Because of this difficulty, the researches involved in this subject often focus on individual artifacts and their assemblages.

According to the reduction concept, some lithic tools will represent a spectrum of reduction stages, which is characterized by patterned alterations of morphology in comparison to the initial forms. These changes depend mainly on the continuous depletion of stone material in the process of rejuvenation of the maintainable parts of stone tools. Based on technical analyses, these sections are sometimes referred to as "active" parts in contrast to the "passive" areas (sensu Boëda 2001), which were rarely or never modified by knapping.

Depending on the wear intensity, resharpening would eventually affect the geometric properties of a tool causing the change of its proportions. If the bifaces considered here were actually continuously reduced, then the pattern of this reduction should be captured by superimposing all specimens and performing the principal component analysis.

\section{Materials}

The main sample consists of handaxes $(\mathrm{N}=42)$ and Keilmesser $(\mathrm{N}=51)$. Their outlines were obtained by scanning the illustrations included in the monographs of the main Late Middle Palaeolithic sites in Southern Poland, namely Wylotne Rock shelter, Biśnik Cave and Pietraszyn 49 (Table 1). This procedure was applied also by A. Costa who used illustrations of bone and stone bifaces from Castel di Guido or R. Iovita, who used drawings of Stelmoor points as a comparative sample in his study regarding Aterian tanged points (Costa 2010; Iovita 2011).

All the stratified sites from which the studied artifacts derive are homogenous in terms of assemblage integrity and stratigraphical sequences. The only exception is Pietraszyn 49 , where lithic artifacts were discovered in a secondary deposit. Despite this fact, the overview of the composition of 


\begin{tabular}{|c|c|c|c|c|c|c|c|}
\hline $\begin{array}{l}\text { Typological } \\
\text { category }\end{array}$ & Site & Raw material & Site type & $\begin{array}{l}\text { Stratigraphic } \\
\text { unit }\end{array}$ & Dating & $\begin{array}{l}\text { Number of } \\
\text { specimens } \\
\text { (N) }\end{array}$ & Reference \\
\hline \multirow[b]{2}{*}{ Handaxes } & Wylotne & Jurrasic flint & rockshelter & $5,6,8 / 7$ & ca. $100-60$ ka BP & 38 & Kozłowski 2006 \\
\hline & Pietraszyn 49 & Erratic flint & open air & & undetermined & 4 & $\begin{array}{l}\text { Fajer et al. } \\
2001\end{array}$ \\
\hline \multirow{5}{*}{ Keilmesser } & Biśnik & Jurrasic flint & cave & $5 / 6$ & $67 \pm 15$ ka BP & 8 & Cyrek 2002 \\
\hline & Wylotne & Jurrasic flint & rockshelter & $5,6,8 / 7$ & ca. $100-60$ ka BP & 32 & Kozłowski 2006 \\
\hline & Pietraszyn 49 & Erratic flint & open air & & undetermined & 8 & $\begin{array}{l}\text { Fajer et al. } \\
2001\end{array}$ \\
\hline & Pietrowice Wielkie 8 & undetermined & surface find & & undetermined & 1 & $\begin{array}{l}\text { Fajer et al. } \\
2001\end{array}$ \\
\hline & Cyprzanów 3 & undetermined & surface find & & undetermined & 1 & $\begin{array}{l}\text { Fajer et al. } \\
2001\end{array}$ \\
\hline \multirow{3}{*}{ Leaf points } & Nietoperzowa Cave & Jurrasic flint & cave & $6,5 a, 4$ & 30-38 ka BP & 25 & $\begin{array}{l}\text { Chmielewski } \\
1961\end{array}$ \\
\hline & Ehringsdorf & Jurrasic flint & cave & & undetermined & 18 & Kot 2013 \\
\hline & Mauern & Jurrasic flint & cave & 4,5 & ca. $60-28$ ka BP & 12 & Kot 2013 \\
\hline Sum & & & & & & 147 & \\
\hline
\end{tabular}

Table 1. List of materials used in the study. // 1. táblázat. A tanulmányban bemutatott kőeszközök.

artifact types from Pietraszyn 49 and their technical features confirms the LMP character of this assemblage and its affiliation to the Central European Keilmessergruppen.

For comparative purposes, an assemblage of 54 LMP leaf points was used as a correlative sample. The reason for choosing such comparative standard is that LMP leaf points are not very distinct from Keilmessergruppen bifaces in terms of chronology and their origin (Richter 2008-2009), yet they represent a more advanced bifacial technology. In the authors opinion, including leaf points in the sample will provide an interesting analogy. The studied points derive mostly from well investigated, stratified sites like Nietoperzowa Cave and Mauern (Table 1).

The sample is suitable for testing the hypothetical reduction trajectories of Keilmessergruppen bifaces. The subsequent typological groups contain artifacts of different shapes and sizes, which allows for tracking the hypothetical reduction patterns. The author followed the classification presented in the monographs (Table 1). Secondly, the studied assemblages come from different types of sites (cave and open air), which gives a more comprehensive view on artifacts variability.

\section{Methods}

\subsection{Artifact orientation, digitization and superimposition}

The author used a standard geometric morphometric method of outline shape analysis based on landmarks (Zelditch et al. 2004: 23). Before the actual analysis a set of procedures, generally consisting of data processing, had to be carried out. They are important for the understanding of the methodology of this study, therefore will be now described.

To project the outline shape, illustrations of the artifacts were scanned with a Canon CanoScan LiDE 210 scanner at $400 \mathrm{dpi}$. The image of each artifact was extracted as a single jpg file and oriented in GIMP according to its axis of symmetry. To allow further comparisons between shapes all outlines had to be oriented in the same manner. The method of orientation applied in this study was first described by McPherron and Dibble (1999) and later improved upon by Costa (2010). In it all the bifaces are oriented around their long axis of symmetry, so that the longest orthogonal lines drawn from a central line were equal in length (Costa 2010: Fig. 2.1b). The tip of a biface was used as the point from which the outline was drawn along the biface's perimeter. This outline will then be transformed into a set of equidistant landmarks (see Fig. 2).

After performing the orientation, a thin plate spline file was created in TpSutility program (Rohlf 2006). This stores all the images in one tps file and allows a further digitization of the images. The tps file with all the images was then opened in TpSDig (Rohlf 2004), a program used mainly for placing landmarks on specimens.

In natural sciences, when the morphology of living or fossil organisms is taken into account, landmarks are often placed on relevant biological structures (e.g. Querino et al. 2002). Of course one can do the same for lithic artifacts by placing landmarks on the tip or base, but this way the complex shape of bifaces would be reduced to just a few landmarks. In the studied case the best way to capture the outline shape is to set a number of landmarks around the perimeter of an artifact by mapping its contour. To allow further comparison between the tool shapes, the landmarks must correspond to each other, i.e. they need to be placed at equal 


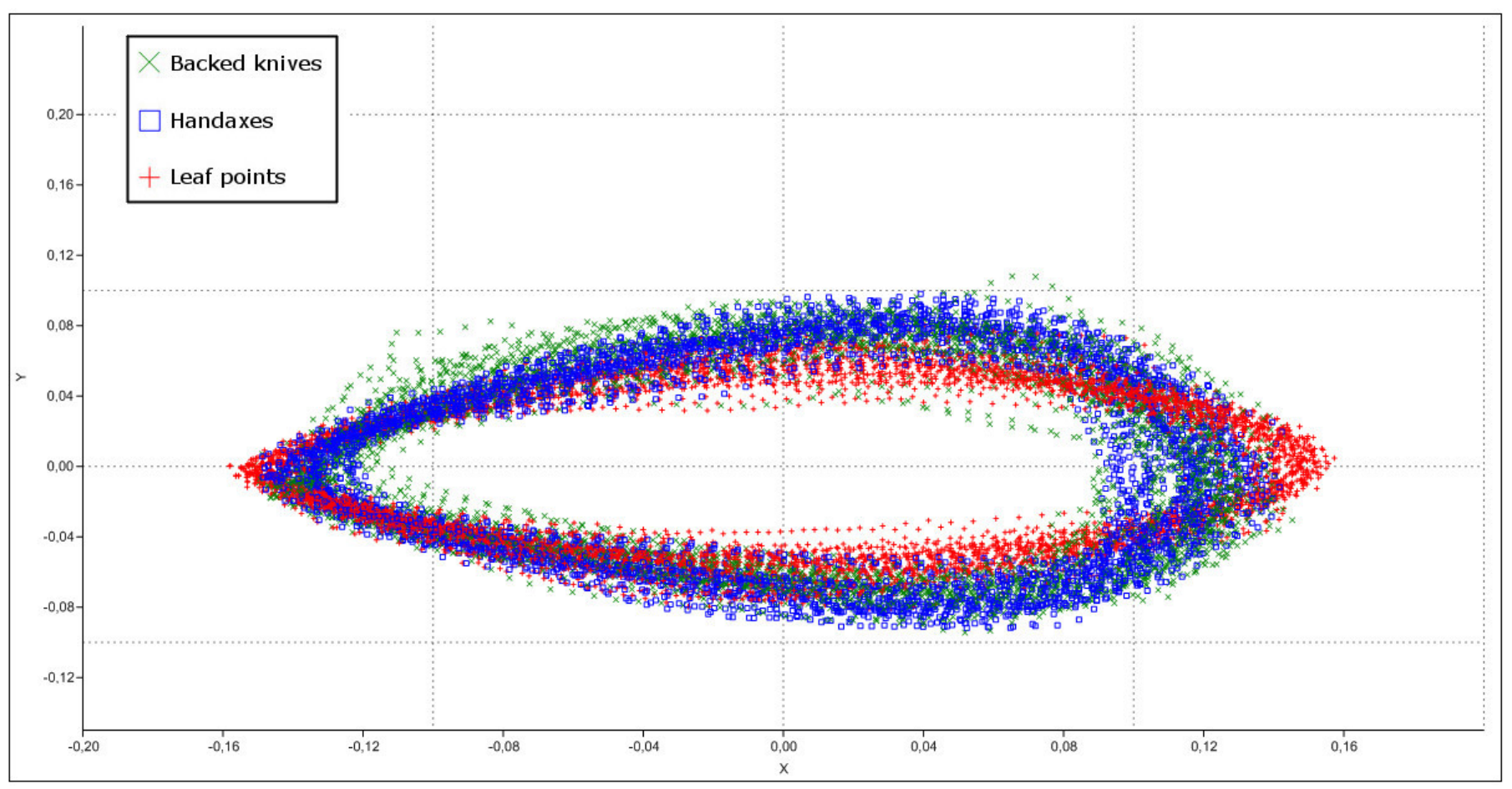

Figure 2. Landmark configuration and the position of all the specimen outlines after conducting the Procrustes superimposition. // 2. ábra. A jelöletek konfigurációja és az összes vizsgált darab körvonalának helyzete Procrustes megfeleltetés elvégzése után.

distances from each other and according to a standardized configuration. Using the TpsDig outline tool it is possible to draw an outline from the tip, along the perimeter of an artifact, and then transform it into a set of equidistant landmarks (Costa 2010). The number of entered landmarks is left for the user to choose. Costa used seventy-five points (Costa 2010: 27), while Iovita employed sixty landmarks (Iovita 2009). These numbers are chosen on a trade off between the labour-cost of hand-digitizing and the accurate delineation of artifacts shape. I decided that 100 landmarks would describe the outline shape with a greater accuracy, since LMP bifaces contain large natural surfaces and are often irregular. After assigning the landmarks for each specimen, the tps data was opened with PAST (Palaeontological Statistics), a program enabling statistical shape analyses (Hammer et al. 2001).

Landmarks are subject to several kinds of displacements in two-dimensional space, such as rotation and translation (Richtsmeier et al. 2002). These may affect the correct orientation of specimens and cause errors during a comparison of artifacts shapes. One should also bear in mind that some of the digitized outlines were represented in a different scale than the others. To eliminate these changes in landmarks position a Procrustes analysis must first be conducted. Procrustes analysis is a set of mathematical operations which transforms the matrix of XY coordinates so that translation, rotation and the difference of scale is eliminated from the assemblage (Rohlf-Slice 1990) (Fig. 2). Additionally all outlines are superimposed around a centroid, which is the 0,0 coordinate on the XY axis (Hammer et al. 2001). This operation subtracts the mean shape referred to as "consensus" from all the coordinate values, allowing for further tracking of shape deformations of specimens in relation to the consensus shape. Superimposition scales bifaces dimensions to a common centroid, equalizing their size, while preserving the original shape (Jungers et al. 1995).

\subsection{Principal component analysis (PCA) with $95 \%$ prediction ellipses}

In geometric morphometrics, PCA is a frequently used method of statistical shape analysis. It allows simplification of complex patterns of shape variation, making them easier to interpret. In the studied case, PCA is applied to recognize shape changes which are caused by continuous resharpening of lithic tools.

The set of landmarks is a $\mathrm{K} \times \mathrm{M}$ matrix, that is, a matrix of $\mathrm{K}$ number of landmarks in $\mathrm{M}$ dimensions (Dryden-Mardia 1998). It is expected that some regions of the tool outlines will overlap since they generally belong to the same typological category, but patterns of their variation and covariation are often complex and difficult to interpret. The purpose of PCA is to simplify those patterns and make them easier to interpret by reducing the number of shape variables (Zelditch et al. 2004: 156). PCA transforms the matrix of landmarks so that most of the variation is described by two hypothetical variables, the so called principal components, which are the X and Y axes on the PCA plot.

To test the accuracy of observations, a 95\% ellipse will be applied as a supplement to the PCA analysis. The ellipse is drawn based on the assumption that the data is subjected to a two-dimensional normal distribution. The orientation of an ellipse depends on the correlation coefficient between the variables, for example, the longer axis of an ellipse is approximately imposed according to the regression line of 


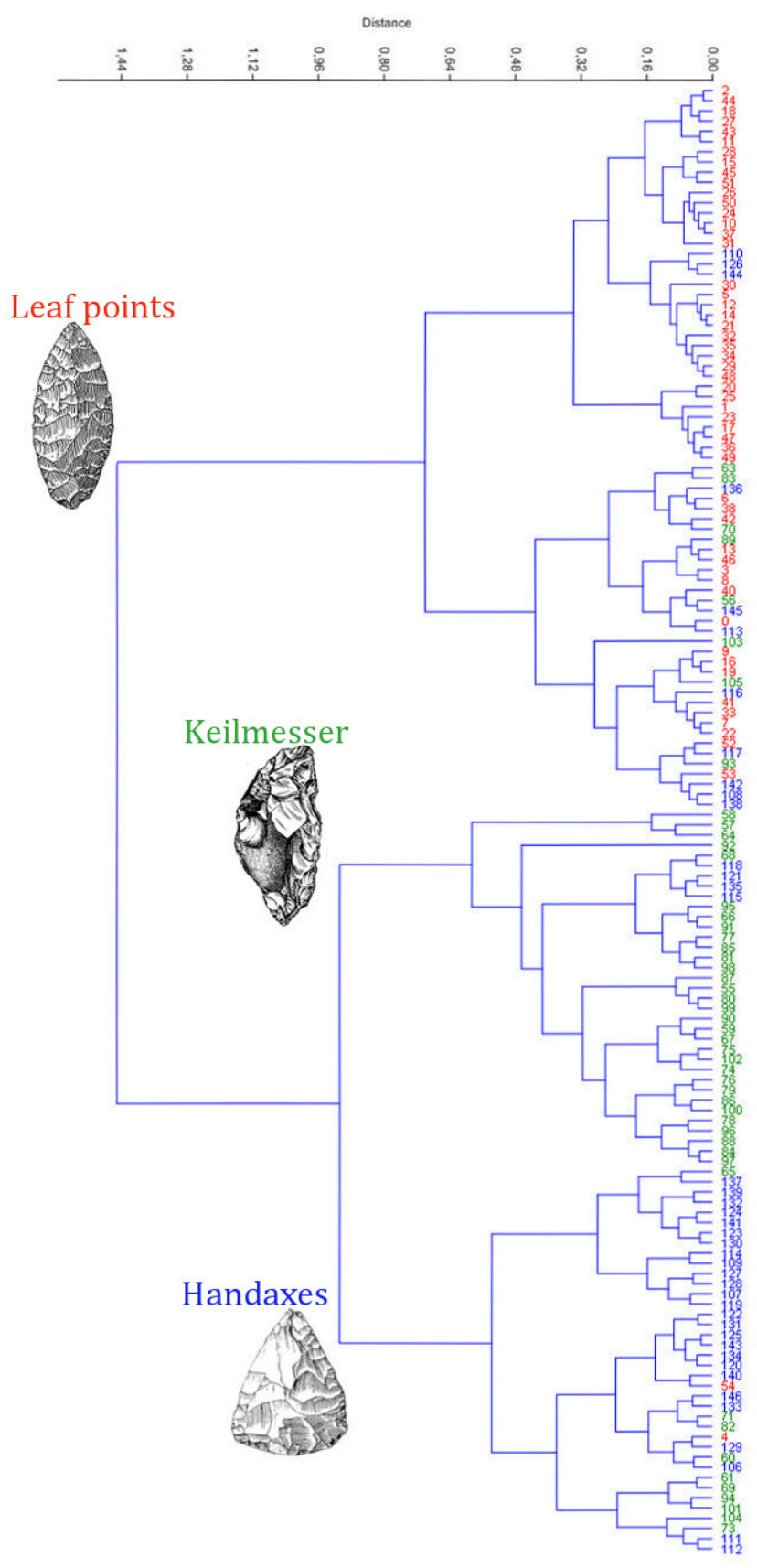

Figure 3. Diagram of the cluster analysis with the Ward's method. // 3. ábra. A klaszteranalízis dendrogramja (Ward metódus).

values. The probability that a new value will fall in the range of the ellipse (for instance 0.95 ) is the parameter determining its size (Tracey et al. 1992).

\subsection{Cluster analysis with the Ward's method}

In order to determine whether the subsequent typological categories established for the analysed bifaces comply with the results of geometric morphometric analysis, the author decided to conduct a cluster analysis. In natural sciences, it is a common way of organizing samples of specimens, which are characterized by high variability. The cladistic analysis groups together specimens, which are most similar in terms of their outline shape, and leaves out those which differ. By that, it forms a hierarchical tree diagram of clusters, which are spaced by taxonomic distance (KaufmanRousseeuw 1990). In the author's opinion, the best variant of cluster analysis for dealing with the problem discussed here is the Ward's method (Ward 1963). Basically, it looks at cluster analysis as an analysis of variance problem, instead of using distance metrics or measures of association. It looks for groups of specimens that it forms into branches, the branches into limbs and eventually into the trunk (de Amorim 2015). If Keilmesser, handaxes and leaf points will be recognized as separate categories, the outcome should be a set of three clusters comprising the outlines of subsequent types of artifacts.

\subsection{Elliptic Fourier analysis (EFA)}

This is a method of shape analysis in landmark-based morphometrics. EFA is based on the results of principal component analysis by following the patterns of regression of shapes designated by $95 \%$ ellipses.

In standard landmark-based morphometrics, the shape of an object is defined by a set of landmarks with relevant coordinates located in two dimensional space (Richtsmeier et al. 2002). Elliptic Fourier turns closed curves designated by landmarks into linear combinations of sinusoidal functions with appropriate multiplicators (amplitudes) (KuhlGiardina 1982; Ferson et al. 1985). By doing so, EFA serves as a more dynamic approximation of shape changes among the studied specimens, especially when these changes are expected to be gradual (such as continuous reduction of lithic tools). The quality of these approximations can be adjusted by changing the number of amplitudes or harmonics. Increasing their number will simply increase the accuracy of shape representation, but the important thing is to select a trade off between the accuracy of the representation and the level of complexity of the analysis. Examining artifacts shapes in a general manner can aid in finding more comprehensive patterns of reduction. In this study, the author have set the number of harmonics at 5 , which gave an accurate overall representation of artifacts form.

\section{Results}

\subsection{Cluster analysis with the Ward's method}

The resulting clusters generally correspond with the typological categories established for the LMP bifacial tools. When setting a brake in the middle of the hierarchical distance (0.80), we observe that three, well defined clusters of sizes 72, 36 and 37 emerge on the diagram (Fig. 3). The greatest overlap appears between the assemblages of handaxes and Keilmesser, since they have been grouped into one, larger cluster at a distance of 0.96 . The cluster of leaf points is best defined, since it forms a branch of the highest taxonomic level, which splits up approximately at a distance of 0.70 . The other branch forms a cluster comprising of leaf points and also some handaxes and a few Keilmesser. 


\begin{tabular}{|c|c|c|c|c|c|c|c|c|}
\hline \multicolumn{3}{|c|}{ Knives } & \multicolumn{3}{|c|}{ Handaxes } & \multicolumn{3}{|c|}{ Leaf points } \\
\hline PC & Eigenvalue & $\%$ variance & PC & Eigenvalue & $\%$ variance & PC & Eigenvalue & $\%$ variance \\
\hline 1 & 0.0049351 & 37.169 & 1 & 0.004922 & 53.873 & 1 & 0.0041795 & 66.185 \\
\hline 2 & 0.0030593 & 23.041 & 2 & 0.0014226 & 15.57 & 2 & 0.000665 & 10.531 \\
\hline 3 & 0.0016673 & 12.557 & 3 & 0.001092 & 11.953 & 3 & 0.0004884 & 7.7349 \\
\hline 4 & 0.0010285 & 7.7463 & 4 & 0.0004367 & 4.7801 & 4 & 0.0002431 & 3.8494 \\
\hline 5 & 0.0005537 & 4.17 & 5 & 0.0003116 & 3.4109 & 5 & 0.0001435 & 2.2717 \\
\hline 6 & 0.0004958 & 3.7341 & 6 & 0.0001802 & 1.9728 & 6 & 0.000112 & 1.7741 \\
\hline 7 & 0.0003602 & 2.7131 & 7 & 0.0001703 & 1.8643 & 7 & $7.82 \mathrm{E}-05$ & 1.2376 \\
\hline 8 & 0.0002323 & 1.7494 & 8 & $1.00 \mathrm{E}-04$ & 1.0941 & 8 & $5.76 \mathrm{E}-05$ & 0.91152 \\
\hline 9 & 0.0001891 & 1.4246 & 9 & $9.10 \mathrm{E}-05$ & 0.99559 & 9 & $4.73 E-05$ & 0.74897 \\
\hline 10 & 0.0001373 & 1.0344 & 10 & $6.23 E-05$ & 0.68244 & 10 & 4.23E-05 & 0.67056 \\
\hline 11 & 0.000132 & 0.99426 & 11 & $5.93 \mathrm{E}-05$ & 0.64853 & 11 & $3.64 \mathrm{E}-05$ & 0.57634 \\
\hline
\end{tabular}

Table 2. Eigenvalues and the percentage variance of the selected principal components generated for each typological group. //

2. táblázat. Az egyes tipológiai csoportok főkomponensei a hozzájuk tartozó százalékos varianciával és sajátértékekkel.

\subsection{Principal component analysis}

The first two principal components describe $56.021 \%$ and $18.544 \%$ of the whole variance and only those PCs were taken into account during elliptic Fourier analysis (Table 3). To get a more comprehensive view on the distribution of specimens, also PCs two and three were taken into account, since their percentage variance is also of significant quantity. The number of generated PCs is equal to the number of all specimens $(\mathrm{N}=147)$, but most of them hold very little of the overall variance, therefore a number of eleven PCs was presented in tables 2 and 3 for comparative purposes.

To compare the eigenvalues and the percentage variance between the assemblages, a set of eleven principal components was also generated for each typological group (Table 3). The percentage variance values indicate that leaf points are the most uniform group in terms of outline shape, as the first two principal components describe $76.716 \%$ of the overall variance. Knives are the most variable typological group in which the values of the percentage variance are more evenly distributed between the individual principal components. This implies that there is no clear trend in the distribution of their outline shapes.

PC1 axis shows the regression of the most expanded tool shapes towards the most contracted ones. It is hard to define the range of distribution shown by PC2 since there are too few specimens scattered according to this principal component (Fig. 4). Most of the knives are distributed according to PC2, but the reason for this arrangement is unclear.

The distribution of specimens according to PCs two and three presents a different view on the outline shapes variability. In this arrangement, most Keilmesser are scattered according to component two, while handaxes and especially leaf points, form a tight cluster at the center of the plot. Most Keilmesser are scattered randomly and without any pattern of distribution. In this arrangement, tools made out of large blanks, with only initial bifacial retouch along the edge are placed in the same range of values as knives with all over bifacial retouch and a concave working edge, which could be considered as exhausted.

\begin{tabular}{|rrr|}
\hline PC & Eigenvalue & \% variance \\
\hline 1 & 0.0082381 & 56.021 \\
\hline 2 & 0.002727 & 18.544 \\
\hline 3 & 0.0010987 & 7.471 \\
\hline 4 & 0.0007311 & 4.9715 \\
\hline 5 & 0.0004667 & 3.1737 \\
\hline 6 & 0.000329 & 2.237 \\
\hline 7 & 0.0002065 & 1.4043 \\
\hline 8 & 0.0001453 & 0.98826 \\
\hline 9 & 0.0001228 & 0.83532 \\
\hline 10 & $8.07 \mathrm{E}-05$ & 0.54844 \\
\hline 11 & $7.08 \mathrm{E}-05$ & 0.48119 \\
\hline
\end{tabular}

Table 3. Eigenvalues and the percentage variance of the selected principal components generated for Keilmesser, handaxes and leaf points altogether. //

3. táblázat. A Keilmesser, szakóca és levélhegy tipológiai csoportok összesített főkomponensei a hozzájuk tartozó százalékos varianciával és sajátértékekkel

Interestingly, according to PC two and three, assemblages of handaxes and leaf points overlap and are distributed almost in the same range of the plot (Fig. 5). The 95\% ellipses designate a range from crudely shaped specimens, clustered in the lower-right part of the plot to finely shaped, elongated handaxes and leaf points, which were placed on the opposite side of the ellipses range. Some handaxes fall out from the range of the prediction ellipse. Curiously, all of these are specimens from Wylotne, which are very similar to each other. They have straight working edges, a broad, straight base and their outline resembles an isosceles triangle (see Fig. 1: b, specimen in the middle).

\subsection{Elliptic Fourier analysis}

The set of Keilmesser outlines was not involved in the EFA, since there were no indication of any reduction pattern in their assemblage. The results of EFA for handaxes show, that there is a significant pattern of shape change consisting of the transition from specimens with rounded or irregular edges to handaxes with slightly concave contour in their midsection and a pronounced tip (Fig. 6). This pattern 


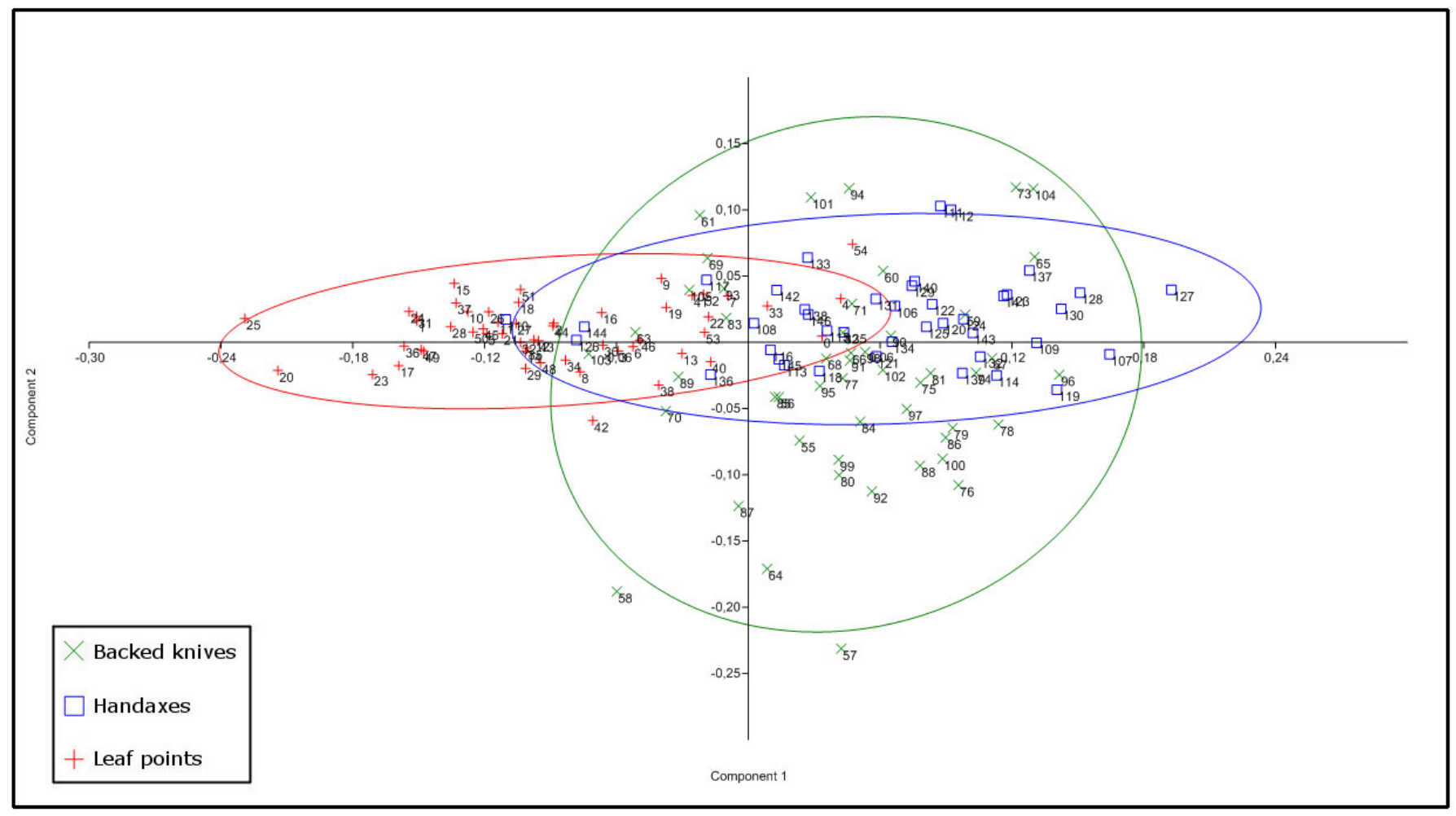

Figure 4. Plot of the PCA analysis for PC one and two with 95\% ellipses. //

4. ábra. Az első és második főkomponens diagramja 95\%-os ellipszisekkel.

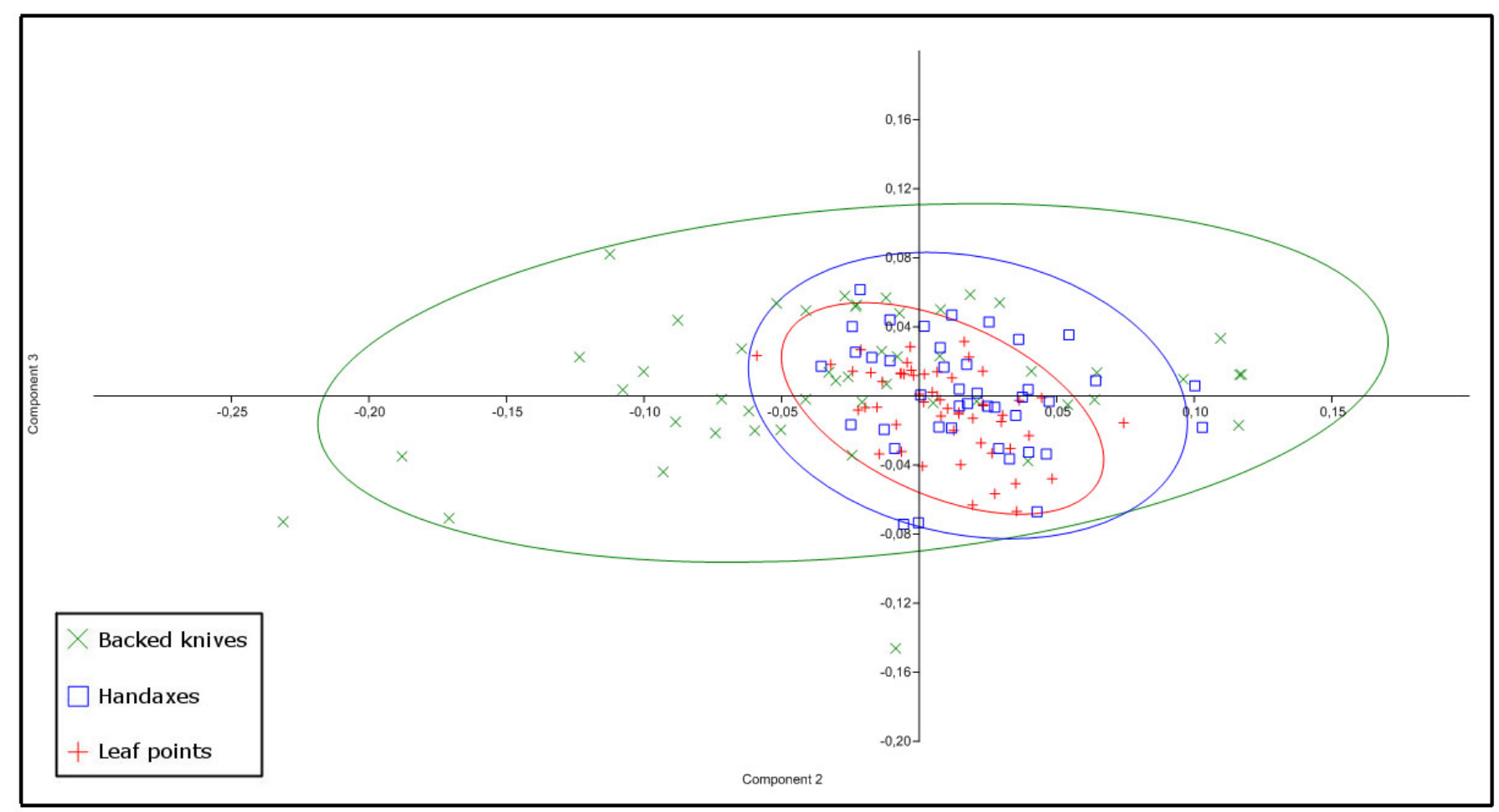

Figure 5. Plot of the PCA analysis for PC two and three with 95\% ellipses. //

5. ábra. A második és harmadik főkomponens diagramja 95\%-os ellipszisekkel. 

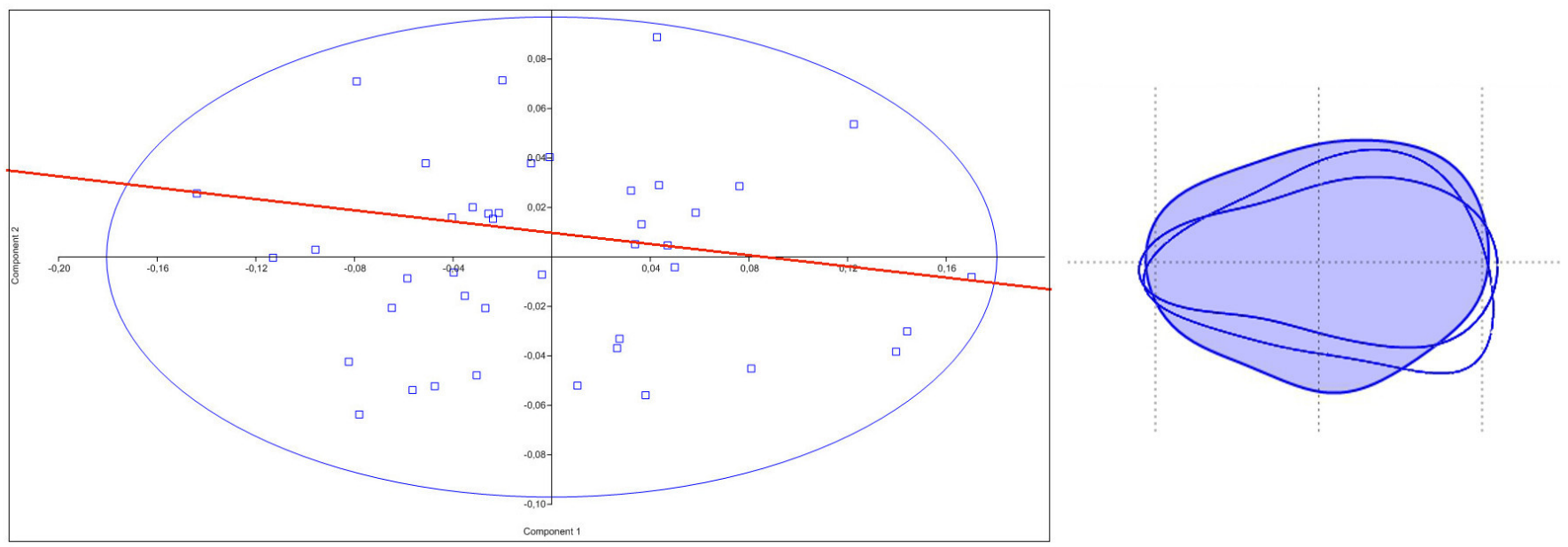

Figure 6. Results of the elliptic Fourier analysis for the handaxes assemblage illustrated by three Fourier shapes.

// 6. ábra. A szakócák elliptikus Fourier analízisének eredményei, három Fourier formával illusztrálva.
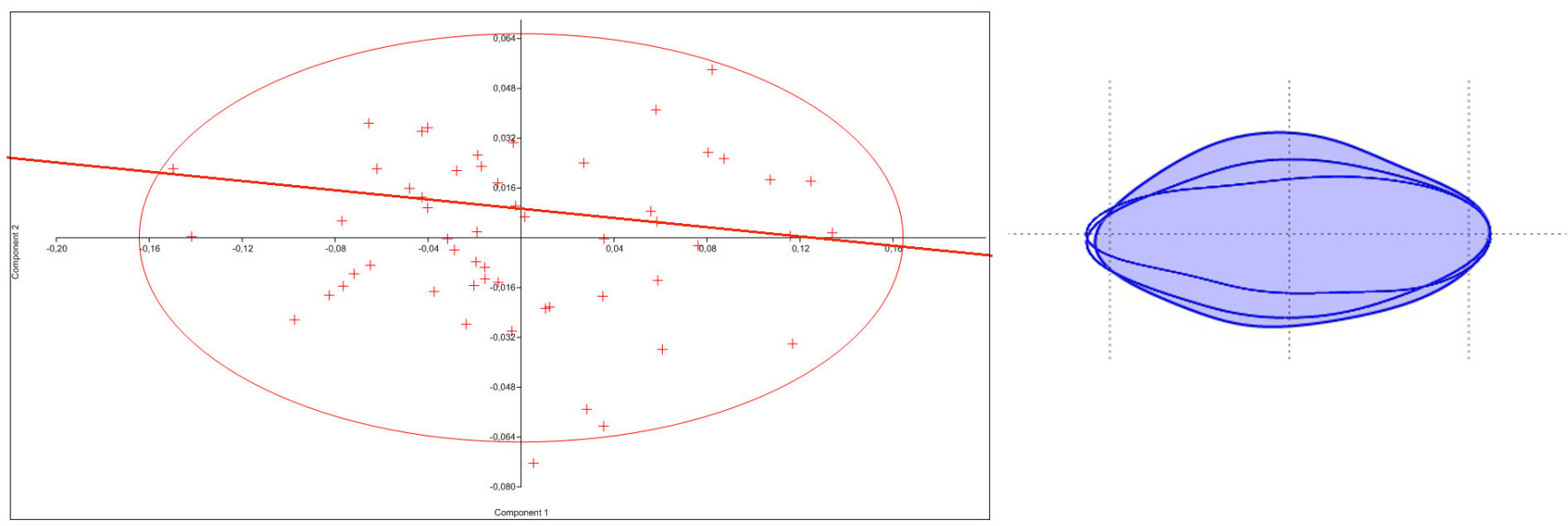

Figure 7. Results of the elliptic Fourier analysis for the leaf point assemblage illustrated by three Fourier shapes. //

7. ábra. A levélhegyek elliptikus Fourier analízisének eredményei, három Fourier formával illusztrálva.

is best emphasized by the three specimens from Wylotne Rockshelter, which were designated by linear regression (see Fig. 1: b).

As it was mentioned before, LMP leaf points sample was used here only for comparative purposes, but the author noticed that it shows an interesting pattern of shape regression. Three Fourier shapes designated by the linear regression clearly show, that there exists a reduction in the midsection of leaf points, while the tip area and the base are held constant (Fig. 7). This pattern is emphasized by the leaf shaped implements from Nietoperzowa Cave and from Mauern.

\section{Discussion}

The results show, that the featured typological categories correspond well with results of the geometric morphometric analysis. There exist common areas between all assemblages, but generally, Keilmesser, handaxes and leaf points form separate clusters in the scope of geometric morphometric analysis. The greatest overlap exists between handaxes and knives. It may be due to the fact, that these are closely related typological categories by means of their origin. Their genetic relation was already suggested by Hahn (1991), and also R. Schild described Keilmesser as "handaxes with a back" (Schild-Wendorf 1977). It can be observed, that in course of the cluster analysis, the specimens have been organised hierarchically. Of the highest significance are the most homogenous clusters, which are usually paired with a quantitatively smaller cluster with diverse composition of specimens. Given the strictly quantitative character of this analysis, these specimens are in the range of statistical error.

One of the most intriguing outcomes of the PCA is the random distribution of Keilmesser. They show no signs of shape regression, which would indicate continuous resharpening. If reduction affected their proportions, then it should come as a diminishing of values on the PCA plot, since the studied assemblage comprises specimens which can be considered as initial as well as exhausted (i.e. Fig. 1: a). On the basis of these observations, it is hard to conclude that reduction was the main reason for the diversity of Keilmesser shapes. 


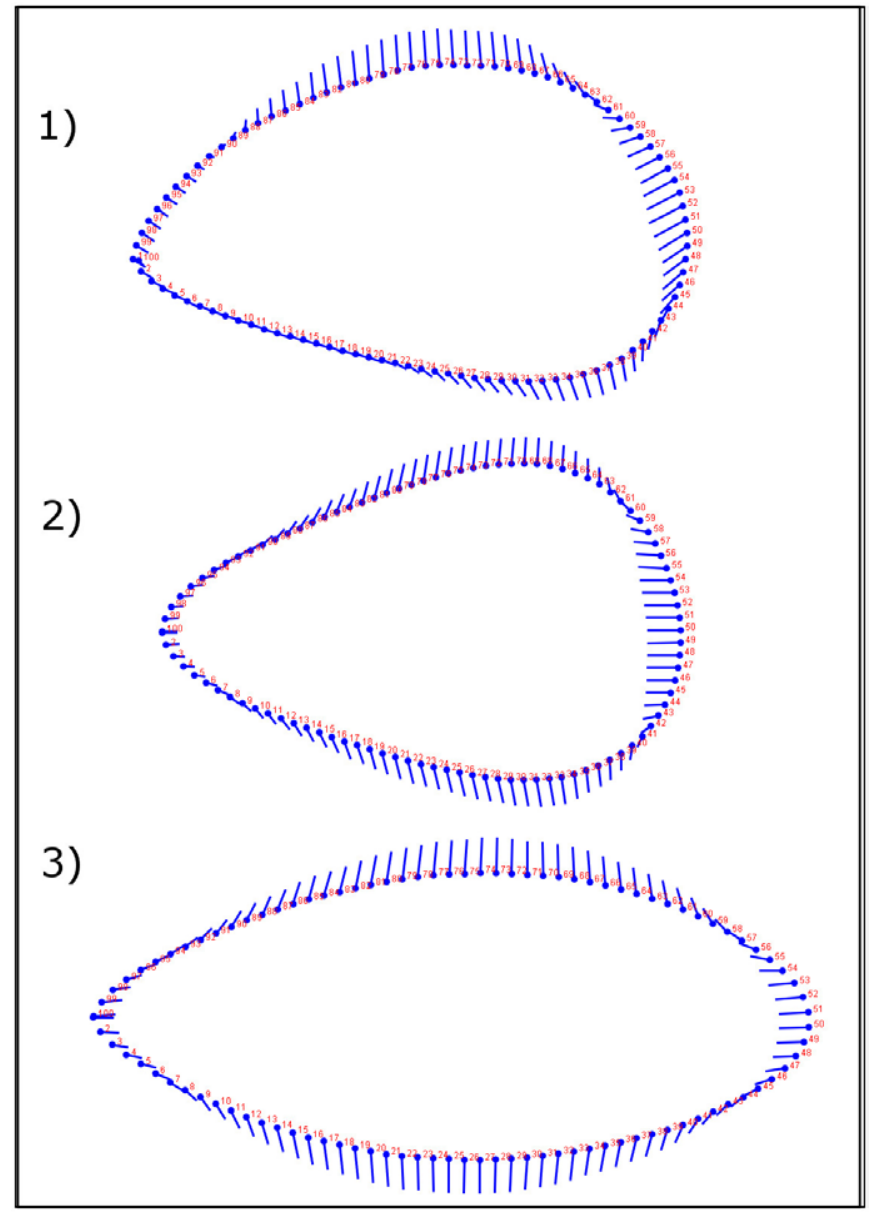

Figure 8. Vectors indicating the shift of landmarks position according to principal component 1 , in the assemblage of Keilmesser (1), handaxes (2) and leaf points (3). //

8. ábra. Az első főkomponens szerinti jelölet-elmozdulást illusztráló vektorok a Keilmesser (1), a szakóca (2) és a levélhegy (3) mintákban.

There exists a strong correlation between the assemblages of handaxes and Keilmesser, especially according to PC two and three. This may indicate a common origin of these typological categories. The similar distribution of handaxes and leaf points suggests, that they generally undergo the same type of shape alterations, namely from specimens with expanded, irregular contour to forms, which are elongated and symmetrical. The discrimination of triangular handaxes in course of the analysis of PC two and three is unclear. In the authors opinion, these PCs probably focus on the resemblance of the outline shapes in terms of tools symmetry. That is probably why Keilmesser were so scattered according to hese PCs and most handaxes and leaf points (which are generally symmetrical) were clustered around the 0,0 value, which is the centroid of a PCA plot.

Most of the variance in the Keilmesser assemblage is caused by the irregularities of natural surfaces, which were preserved in the back and at the base of these tools, probably for improving prehension. PCA landmark vectors show, that regions of the tip and the cutting edge are mostly held constant, while the back and the base undergo serious deformations as compared to the consensus shape (Fig. 8). This indicates that knives were often made of nodules or plaquettes of raw material which significantly differed in sizes and shapes which affected the form of finished tools.
The outline shape of the "active" sections, and especially the working edge, are very similar in most specimens.

The position of handaxes on the PCA plot confirms a shift of proportions from expanded shapes with an oval contour (Fig. 4: specimen 107 - Fajer et al. 2001: Fig. 3; specimen 127, 128 - Targosz 2006: Plate 42, 46) through forms with straight edges and a triangular contour (i.e. Fig. 4: specimen 130, 123 - Boroń 2006: Plate 99; Targosz 2006: Plate 40), to handaxes with straight or slightly concave edges, which are intensively elaborated with flat, surface retouch (Fig. 4: specimens 108, 110, 142 - Fajer et al. 2001: Fig. 4a; Targosz 2006: Plate 43; Fig. 3: 110, 126, 144 - Targosz 2006: Plate 44, 45; Boroń 2006: Plate 104). It is notable that handaxes and leaf points are similarly distributed, mainly according to PC1, which generally shows the transition from broad, oval shapes to the most elongated specimens.

Acheulean handaxes showed a pattern of reduction involving mainly the rejuvenation of the tip. This resulted in the transition from a pointed to oval morphology (McPherron 1995; 1999; 2000; 2003; Iovita-McPherron 2011). In the studied assemblage of KMG handaxes an opposite pattern can be observed. It seems that reduction was in this case aimed at resharpening, or simply depleting the stone material from the edges, but leaving the tip relatively unmodified. In general, this may have had an impact on handaxe outline shape, causing the observed transition from oval morphology towards handaxes with straight or concave edges and a pronounced tip.

The EFA also revealed an interesting pattern present within the leaf point assemblage. The width of these implements undergoes evident contraction, which obviously is due to the changes in leaf point manufacture. The technology of leaf points production changes significantly through time. Throughout the time span of the leaf point industry, they are gradually being replaced by points made of slender blades with flat retouch covering only their proximal or distal sections (the so-called "Jerzmanowice points"). This pattern is observable in the younger episodes of occupation of the Nietoperzowa Cave (Fig. 1: c) and in Mauern as well (Kozłowski 2004: 400-402). The outline shape deformations showed by EFA are very regular and they apply only to the edges of the leaf points, while the proximal and distal areas remain constant, as if the intention was to maintain elongation as well as the tip and base within exactly the same proportions (Fig. 7).

\section{Conclusions}

The results indicate that the applied method of statistical shape analysis coincides well with the typological categories established for LMP bifaces. However, the outcome of cluster and principal component analysis point out that the subsequent assemblages of LMP biface types are indeed fuzzy sets. All of the studied groups of specimens corresponding with the subsequent tool types contain some specimens of other types. This way, all the typological categories create mixed assemblages, which overlap at some point. This is 
probably due to the general similarity of outline shapes featured by LMP bifaces.

In the light of PCA, it cannot be confirmed, that Keilmesser were continuously reduced in course of resharpening, at least not to the point where it would significantly alter the morphology of these tools. Instead, the results suggest, that in the studied assemblage we are dealing with outline shape variation, which is caused by irregularities of raw material blanks, out of which Keilmesser were made.

The application of elliptic Fourier analysis have yielded some interesting patterns of shape change among handaxes and leaf points. In the first case, we may be dealing with a pattern of reduction, which was due to the continuous depletion of dulled edges of handaxes. This pattern may also be an effect of the knappers intention to obtain a more elongated biface with a pronounced tip.

The pattern observed in the leaf point assemblage is partly an effect of the changing technology of leaf points production. However, the relative constancy with which the proximal and distal parts of these tools were shaped throughout the subsequent episodes of the settlement of Nietoperzowa Cave remains unexplained. At this point, it is hard to properly interpret this pattern of shape alteration. The author would suggest that such change may be due to the gradual improvement of leaf points performance, nevertheless further research on this subject needs to be conducted.

Although the applied method is limited, because it takes no account of the technical and metric features, it may be useful in constructing holistic models of artifact shape reduction (occurring synchronically or diachronically). Nevertheless, to avoid misinterpretation, one should bear in mind two limitations encountered in the course of the discussed analysis. Firstly, the method serves best when applied to quantitatively large assemblages. Lower and Middle Palaeolithic bifaces are often irregular, and a larger sample (one preferably assembled from several sites) will allow for a more comprehensive view. Secondly, including a test sample of different provenance than the main assemblage can assist the interpretation of shape change trajectories and bring in potentially interesting results.

\section{References}

Azavedo S., Charlin J., González-José R. 2014. Identifying design and reduction effects on lithic projectile point shapes. Journal of Archaeological Science 41: 297-307. https://doi.org/10.1016/j. jas.2013.08.013

Boëda E. 2001. Détermination des Unités Techno-Fonctionelles de pièces bifaciales provenant de la couche Acheuléenne C'3 Base du site de Barbas I. In: Cliquet D. (dir.), Les industries à outils bifaciaux du Paléolithique moyen d'Europe occidentale - Actes de la table-ronde internationale organisée à Caen (Basse-Normandie - France) 14 et 15 octobre 1999. E.R.A.U.L. 98, Liège: Université de Liège, 51-75.

Boroń T. 2006. Typology and classification of bifaces from Wylotne site in Ojców. In: Kozłowski S. K. (ed.), Wylotne and Zwierzyniec.
Paleolithic Sites in Southern Poland. Kraków: The Polish Academy of Arts and Sciences - Warsaw University, 225-245.

Bosinski G. 1967. Die mittelpaläolithischen Funde im westlichen Mitteleuropa. Fundamenta A/4, Köln-Graz: Böhlau-Verlag.

Buchanan B., Johnson E., Strauss R. E., Lewis P. J. 2007. A Morphometric Approach to Assessing Late Paleoindian Projectile Point Variability on the Southern High Plains. Plains Anthropologist 52(203): 279-299. https://doi.org/10.1179/ pan.2007.019

Buchannan B., Collard M. 2010. A geometric morphometrics-based assessment of blade shape differences among Paleoindian projectile point types from western North America. Journal of Archaeological Science 37: 350-359. https://doi.org/10.1016/j. jas.2009.09.047

Charlin J., González-José R. 2012. Size and shape variation in late Holocene projectile points of Southern Patagonia: a geometric morphometric study. American Antiquity 77(2): 221-242. https:// doi.org/10.7183/0002-7316.77.2.221

Chmielewski W. 1961. Civilisation de Jerzmanowice. WrocławWarsaw-Kraków: Zaklad Narodowy Imienia Ossolińskich Wydawnictwo Polskiej Akademii Nauk.

Chmielewski W. 1969. Ensembles micoquo-prondikiens en Europe Centrale. Geographie polonica 17: 371-386.

Cyrek K. (ed.) 2002. Jaskinia Biśnik. Rekonstrukcja zasiedlenia jaskini na tle zmian środowiska przyrodniczego. Torun: Wydawnictwo Uniwersytetu Mikołaja Kopernika.

Costa A. G. 2010. A Geometric Morphometric Assessment of Plan Shape in Bone and Stone Acheulean Bifaces from the Middle Pleistocene Site of Castel di Guido, Latium, Italy. In: Lycett S. J., Chauhan P. R. (eds.), New Perspectives on Old Stones: Analytical Approaches to Paleolithic Technologies. New York: Springer, 2341. https://doi.org/10.1007/978-1-4419-6861-6_2

de Amorim R. C. 2015. Feature Relevance in Ward's Hierarchical Clustering Using the Lp Norm. Journal of Classification 32(1): 4662. https://doi.org/10.1007/s00357-015-9167-1

Dibble H. 1984. Interpreting typological variation of Middle Palaeolithic scrapers: Function, style or sequences of reduction? Journal of Field Archaeology 11: 431-436. https://doi. org/10.2307/529322

Dibble H. 1987. The interpretation of Middle Palaeolithic scraper morphology. American Antiquity 52: 109-117. https://doi. org/10.2307/281062

Dibble H. 1995. Middle Palaeolithic Scraper reduction: background, clarification and overview of evidence to date. Journal of Archaeological Method and Theory 2: 299-368. https://doi. org/10.1007/BF02229003

Dibble H., Rolland N. 1990. A New Synthesis of Middle Palaeolithic Variability. American Antiquity 55(3): 480-499. https://doi. org/10.2307/281279

Dryden I. L., Mardia K. V. 1998. Statistical Shape Analysis. Chichester: John Wiley \& Sons.

Eren M. I., Lycett S. J. 2012. Why Levallois? A Morphometric Comparison of Experimental 'Preferential' Levallois Flakes versus Debitage Flakes. PLoS ONE 7(1): e29273 https://doi.org/10.1371/ journal.pone. 0029273

Fajer M., Foltyn E., Kozłowski J. K. 2001. Uwagi o kulturze mikockiej na Górnym Śląsku. Przyczynek do genezy kultury mikockiej w Europie Środkowej. Archeologia Polski 46: 31-66.

Feliks J. 2008. Phi in the Acheulian: Lower Palaeolithic intuition and the natural origins of analogy. In: Bednarik R. G., Hodgson D. (eds.), Pleistocene palaeoart of the world. BAR International Series 
1804, Oxford: Archaeopress, 11-31.

Ferson S., Rohlf F. J., Koehn R. K. 1985. Measuring shape variation of two-dimensional outlines. Systemnatic Zoology 34: 59-68. https://doi.org/10.1093/sysbio/34.1.59

Gowlett J. A. J. 2006. The elements of design form in Acheulian bifaces: modes, modalities, rules and language. In: Goren-Inbar N., Sharon G. (eds.), Axe Age: Acheulian Tool-making from Quarry to Discard. London: Equinox, 203-221.

Hahn J. 1991. Erkennen und Bestimmen von Stein- und Knochenartefakten. Einführung in die Artefaktmorphologie. Archaeologica Venatoria 10, Tübingen: Verlag Archaeologica Venatoria.

Hammer Ø., Harper D. A. T., Ryan P. D. 2001. PAST: Paleontological statistics package for education and data analysis. Palaeontologia Electronica 4(1): 9 (http://palaeo-electronica.org/2001_1/past/ issue1_01.htm)

Hauser O. 1916. La Micoque. Die Kultur einer neuen Diluvialrasse. Leipzig: Veit.

Iovita R. 2009. Ontogenetic scaling and lithic systematics: method and application. Journal of Archaeological Sciece 36: 1447-1457. https://doi.org/10.1016/j.jas.2009.02.008

Iovita R. P.2010. Quantifying and comparing stone tool resharpening trajectories with the aid of elliptical Fourier analysis. In: Lycett S., Chauhan P. (eds.), New Perspectives on Old Stones: Analytical Approaches to Palaeolithic Technologies. New York: Springer, 235253. https://doi.org/10.1007/978-1-4419-6861-6_10

Iovita R. 2011. Shape Variation in Aterian Tanged Tools and the Origins of Projectile Technology: A Morphometric Perspective on Stone Tool Function. PLoS ONE 6(12): e29029. https://doi. org/10.1371/journal.pone.0029029

Iovita R., McPherron S. P. 2011. The handaxe reloaded: A morphometric reassessment of Acheulian and Middle Paleolithic handaxes. Journal of Human Evolution 61: 61-74. https://doi. org/10.1016/j.jhevol.2011.02.007

Jöris O. 1994. Neue Untersuchungen zum Mittelpaläolithikum von Buhlen, Hessen. Technologische Studien zur Pradniktechnik in Horizont IIIb des Oberen Fundplatzes. Ethnographisch Archäologische Zeitschrift 35: 88-97.

Jöris O. 2001. Der spätmittelpaläolithische Fundplatz Buhlen (Grabungen 1966-69). Stratigraphie, Steinartefakte und Fauna des Oberen Fundplatzes. Universitätsforschungen zur prähistorischen Archäologie 73, Bonn: Dr. Rudolf Habelt GmbH.

Jöris O. 2006. Bifacially backed knives (Keilmesser) in the Central European Middle Palaeolithic. In: Goren-Inbar N., Sharon G. (eds.), Axe Age: Acheulian Tool-making from Quarry to Discard. London: Equinox, 287-310.

Jungers W. L., Falsetti A. B., Wall C. E. 1995. Shape, relative size, and size-adjustments in morphometrics. Yearbook of Physical Anthropology 38: 137-161. https://doi.org/10.1002/ ajpa.1330380608

Kaufman L., Rousseeuw P. J. 1990. Finding Groups in Data: An Introduction to Cluster Analysis. New York: Wiley. https://doi. org/10.1002/9780470316801

Kelly R. L. 1988. The Three Sides of a Biface. American Antiquity 53(4): 717-734. https://doi.org/10.2307/281115

Kohn M., Mithen S. 1999. Handaxes: Products of sexual selection? Antiquity 73: 518-526. https://doi.org/10.1017/ S0003598X00065078

Kot M. A. 2013. The Earliest Middle Palaeolithic Bifacial Leafpoints in Central and Southern Europe. Technological Approach. Unpublished PhD Thesis, Warsaw University Faculty of History, Warsaw.
Kozłowski J. K. 2004. Świat przed „rewolucjq” neolitycznq. Wielka Historia Świata 1, Kraków-Warszawa: Fogra-Świat Książki.

Kozłowski S. K. (eds.) 2006. Wylotne and Zwierzyniec. Paleolithic Sites in Southern Poland. Kraków: The Polish Academy of Arts and Sciences - Warsaw University.

Krukowski S. 1939-1948. Paleolit. Prehistoria ziem polskich. In: Krukowski S., Kostrzewski J., Jakimowicz R. (red.), Encyklopedia Polska, t. 4, cz. 1, dział 5, Kraków: PAU, 1-117.

Kuhl F. P., Giardina C. R. 1982. Elliptic Fourier features of a closed contour. Computer Graphics and Image Processing 18: 236-258. https://doi.org/10.1016/0146-664X(82)90034-X

Lycett S. J., Von Cramon-Taubadel N., Gowlett J. A. J. 2010. A comparative 3D geometric morphometric analysis of Victoria West cores: implications for the origins of Levallois technology. Journal of Archaeological Science 37: 1110-1117. https://doi. org/10.1016/j.jas.2009.12.011

Marks A. E., Brugal J.-Ph., Chabai V. P., Monigal K., Goldberg P., Hockett B., Peman E., Elorza M., Mallol C., 2002. Le gisement pléistocène moyen de Galeria Pesada (Estrémadure, Portugal): premiers résultats. Paléo 14: 77-100.

McPherron S. P. 1995. A re-examination of the British biface data. Lithics 16: 47-63.

McPherron S. P. 1999. Ovale and pointed handaxe assemblages: two points make a line. Préhistoire Européenne 14: 9-32.

McPherron S. P. 2000. Handaxes as a measure of the mental capabilities of early hominids. Journal of Archaeological Science 27: 655-663. https://doi.org/10.1006/jasc.1999.0467

McPherron S. P. 2003. Technological and typological variability in the bifaces from Tabun Cave, Israel. In: Soressi M., Dibble H. L. (eds.), Multiple approaches to the study of bifacial technologies. Philadelphia: University of Pennsylvania Museum of Archaeology and Anthropology, 55-76.

McPherron S. P., Dibble H. L. 1999. Stone tool analysis using digitized images: examples from the Lower and Middle Paleolithic. Lithic Technology 24(1): 38-52. https://doi.org/10.1080/01977261.1999.11 720944

Migal W., Urbanowski M. 2006. Pradnik knives reused. Experimental approach. In: Wiśniewski A., Płonka T., Burdukiewicz J. M. (eds.), The Stone: Technique and Technology. Wrocław: Uniwersytet Wrocławksi, Instytut Archeologii - SKAM Stowarzyszenie Krzemieniarskie, 73-89.

Pastoors A. 2001. Die mittelpaläolithische Freilandstation von Salzgitter-Lebenstedt. Genese der Fundstelle und Systematik der Steinbearbeitung. Salzgitter-Forschungen 3, Salzgitter: Archiv der Stadt Salzgitter.

Pastoors A., Schäfer J., 1999. Analyse des états techniques de transformation, d'utilisation et états post dépositionelles illustrée par un outil bifacial de Salzgitter-Lebenstedt (FRG). Préhistoire Européenne 14: 33-47.

Porr M. 2005. The making of biface and the making of the individual. In: Gamble C., Porr M. (eds.), The Hominid Individual in Context: Archaeological investigations of Lower and Middle Palaeolithic landscapes, locales and artifacts. New York: Routledge, 68-81.

Querino R. B., de Moraes R. C. B., Zucchi R. A. 2002. Relative Warp Analysis to Study Morphological Variations in the Genital Capsule of Trichogramma pretiosum Riley (Hymenoptera: Trichogrammatidae). Neotropical Entomology 31(2): 217-224. https://doi.org/10.1590/S1519-566X2002000200007

Richter J. 1997. Der G-Schichten-Komplex der Sesselfelsgrotte. Zum Verständnis des Micoquien. Sesselfelsgrotte III. Quartär-Bibliothek 7, Saarbrücken: Saarbrücker Druckerei und Verlag. 
Richter J. 2000. Social memory among late Neanderthals. In: Orschiedt J., Weniger G.-C. (eds.), Neanderthals and Modern Humans - Discussing the Transition. Central and Eastern Europe from 50.000 - 30.000 B.P. Mettmann: Neanderthal Museum, $30-41$.

Richter J. 2002. Die 14C-Daten aus der Sesselfelsgrotte und die Zeitstellung des Micoquien/M.M.O. Germania 80: 1-22.

Richter J. 2008-2009. The role of leaf points in the Late Middle Palaeolithic Germany. Praehistoria 9-10: 99-113.

Richtsmeier J. T., Deleon V. B., Lele S. R. 2002. The Promise of Geometric Morphometrics. Yearbook of Physical Anthropology 45: 63-91. https://doi.org/10.1002/ajpa.10174

Rohlf F. J. 2004. tpsDig. Version 1.40. Stony Brook: SUNY.

Rohlf F. J. 2006. tps Utility Program. Version 1.38. Stony Brook: SUNY.

Rohlf F. J., Slice D. E. 1990. Extensions of the Procrustes method for the optimal superimposition of landmarks. Systematic Zoology 39: 40-59. https://doi.org/10.2307/2992207

Rolland N. 1988. The interpretation of Middle Palaeolithic variability. Man 16: 15-42. https://doi.org/10.2307/2801973

Ruebens K. 2006. A typological dilemma: Micoquian elements in continental Northwestern Europe during the Last Glacial Cycle (MIS 5d-3). Lithics: The Journal of the Lithic Studies Society 27: $58-73$.

Schild R., Wendorf F. 1977. The Prehistory of Dakhla Oasis and Adjacent Desert. Wrocław-Warszawa: Ossolineum.

Shott M. J. 1995. How much is a scraper? Curation, use rates, and the formation of scraper assemblages. Lithic Technology 20: 53-72.

Shott M., Weedman K. L. 2007. Measuring reduction in stone tools: an ethnoarchaeological study of Gamo hidescrapers from Ethiopia. Journal of Archaeological Science 34: 1016-1035. https:// doi.org/10.1016/j.jas.2006.09.009

Sobczyk K. 1975. Problem prądnika w świetle taksonomii numerycznej. Sprawozdania Archeologiczne 27: 255-269.

Solecki R. L., Solecki R. S. 2004. Bifaces and the Acheulian industries of Yabroud Shelter I, Syria. In: Toussaint M., Draily C., Cordy J.M. (eds.), General Sessions and Posters. Section 4: Human Origins and the Lower Palaeolithic. Acts of the XIVth UISPP Congress, Liège 2001. BAR International Series 1272, Oxford: Archaeopress, 37-39.

Targosz M. 2006. Analysis of the flint material of MicoquianPradnikian culture from layer 6 at Wylotne Rockshelter in Ojców. In: Kozłowski S. K. (ed.), Wylotne and Zwierzyniec. Paleolithic Sites in Southern Poland. Kraków: The Polish Academy of Arts and Sciences - Warsaw University, 107-160.

Thulman D. K. 2012. Discriminating Paleoindian point types from Florida using landmark geometric morphometrics. Journal of Archaeological Science 39: 1599-1607. https://doi.org/10.1016/j. jas.2012.01.004

Tracey N. D., Young J. C., Mason R. L. 1992. Multivariate control charts for individual observations. Journal of Quality Technology 2: 88-95. https://doi.org/10.1080/00224065.1992.12015232

Urbanowski M. 2009. Middle Palaeolithic Handaxes: The Case of Wylotne Rockshelter. In: Burdukiewicz J. M., Cyrek K., Dyczek P., Szymczak K. (eds.), Understanding the Past. Warsaw: University of Warsaw, 365-375.

Ward J. H. Jr. 1963. Hierarchical Grouping to Optimize an Objective Function. Journal of the American Statistical Association 58: 236244. https://doi.org/10.1080/01621459.1963.10500845

Wenban-Smith F. F. 2004. Handaxe typology and Lower Palaeolithic cultural development: ficrons, cleavers and two giant handaxes from Cuxton. Lithics 25: 11-21.
Wynn T. 1996. The evolution of tools and symbolic behaviour. In: Lock A., Peters C. R. (eds.), Handbook of Human Symbolic Evolution. Oxford: Oxford University Press, 263-287.

Zelditch M. L., Swiderski D. L., Sheets D. H., Fink W. L. 2004. Geometric morphometrics for biologists: a primer. London: Elsevier Academic Press.

\section{SKAM 2014 Article}

This study was presented at the 11th SKAM Lithic Workshop: the multifaceted biface - Bifacial technology in Prehistory. 20th-22nd of October, 2014, Miskolc, Hungary.

The conference papers are published in the Litikum Journal volumes as special contributions. Informations about the conference as well as the abstract book are available on the SKAM 2014 website: http://skam.pannontenger.hu 